\title{
The ACO Rules - Striking the Balance between Participation and Transformative Potential
}

\section{Citation}

Rosenthal, Meredith B., David M. Cutler, and Judith Feder. 2011. "The ACO Rules - Striking the Balance Between Participation and Transformative Potential." N Engl J Med 365 (4) (July 28): e6. doi:10.1056/nejmp1106012.

\section{Published Version}

doi:10.1056/NEJMp1106012

\section{Permanent link}

http://nrs.harvard.edu/urn-3:HUL.InstRepos:26640486

\section{Terms of Use}

This article was downloaded from Harvard University's DASH repository, and is made available under the terms and conditions applicable to Other Posted Material, as set forth at http:// nrs.harvard.edu/urn-3:HUL.InstRepos:dash.current.terms-of-use\#LAA

\section{Share Your Story}

The Harvard community has made this article openly available.

Please share how this access benefits you. Submit a story.

\section{Accessibility}



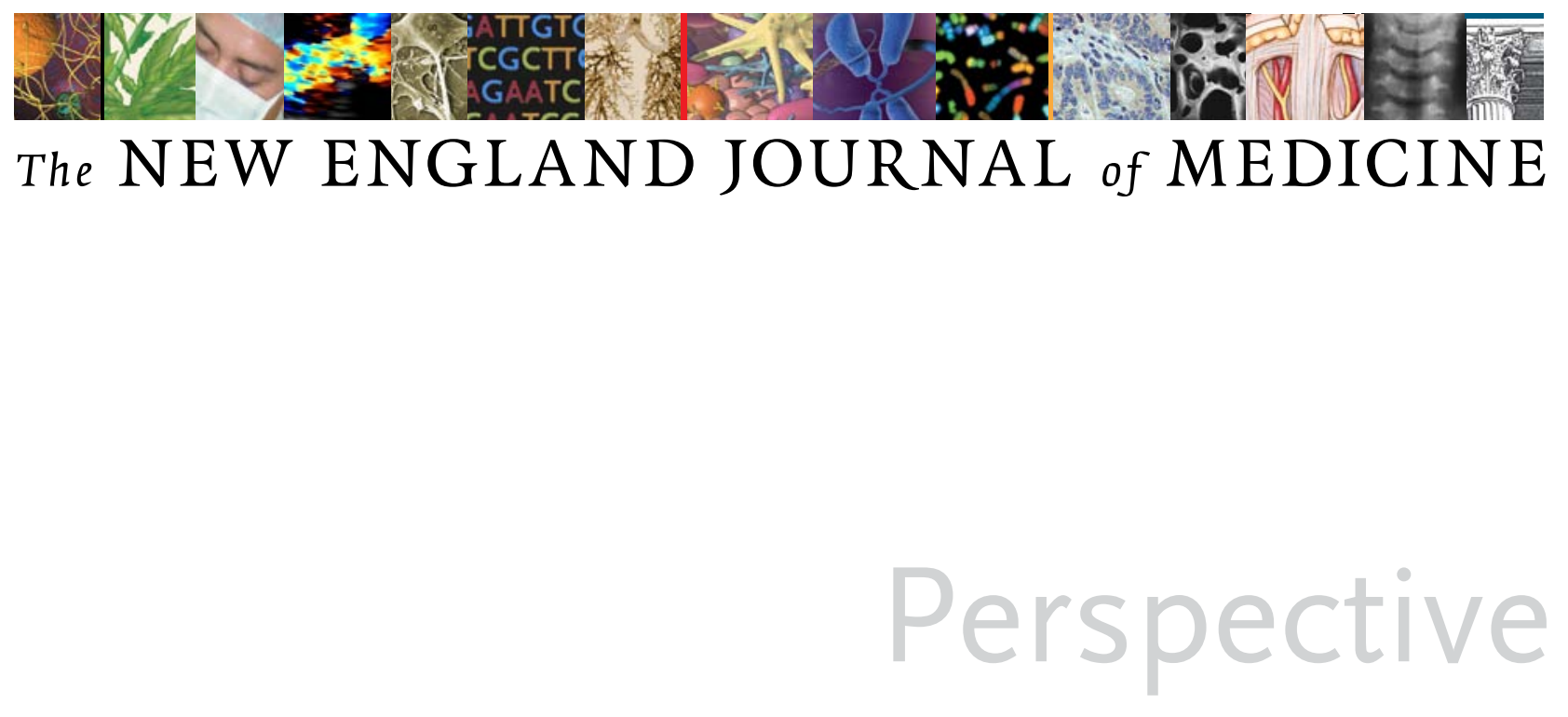

\section{The ACO Rules - Striking the Balance between Participation and Transformative Potential}

Meredith B. Rosenthal, Ph.D., David M. Cutler, Ph.D., and Judith Feder, Ph.D.

\section{Tn April, the Centers for Medicare and Medicaid Services (CMS) issued a long-awaited Notice of Proposed Rulemaking with a proposed policy for the accountable care organization (ACO) program}

authorized by the Affordable Care Act (ACA). Under this policy, ACOs could participate in one of two types of 3-year arrangements. In the first path, in years 1 and 2 they would be eligible to share any savings they achieved relative to a spending target without accepting "downside" risk. In year 3 , the ACOs would be required to repay Medicare for a percentage of any spending over their target level. In the second path, an ACO could accept downside risk beginning in year 1 and thereby be eligible for a higher proportion of any savings ( $60 \%$ vs. $50 \%$ ). All shared-savings payments would be contingent on meeting established quality goals and minimum savings thresholds $3.9 \%$ for the one-sided risk model and $2 \%$ for the two-sided risk model). Shared-savings payments to the ACO could not exceed $7.5 \%$ of the total target costs; payments by the ACO to Medicare would not exceed $5 \%$ of those costs in the first year it accepted downside risk (then $7.5 \%$ in year 2 and $10 \%$ in year 3.)

Since the proposed policy was issued, there has been a flurry of analysis and criticism, much of which concerns whether the new payment terms offer sufficient financial rewards to attract provider participation. But the regulation is better assessed as a solution to a contracting problem, which requires that it accomplish two goals: saving money for Medicare without causing substantial adverse consequences, and encouraging enough groups to participate. We believe there are ways for CMS to improve participation in ACOs without sacrificing the workhorse provisions of the new policy.

The proposed regulations rely on limited risk sharing and the imposition of quality standards in order to attain a balance among incentives for cost control, risk, and maintenance of high-value service delivery. Unlike full capitation, the ACO arrangements limit risk in two ways. First, ACO profits are affected only by changes in Medi- 


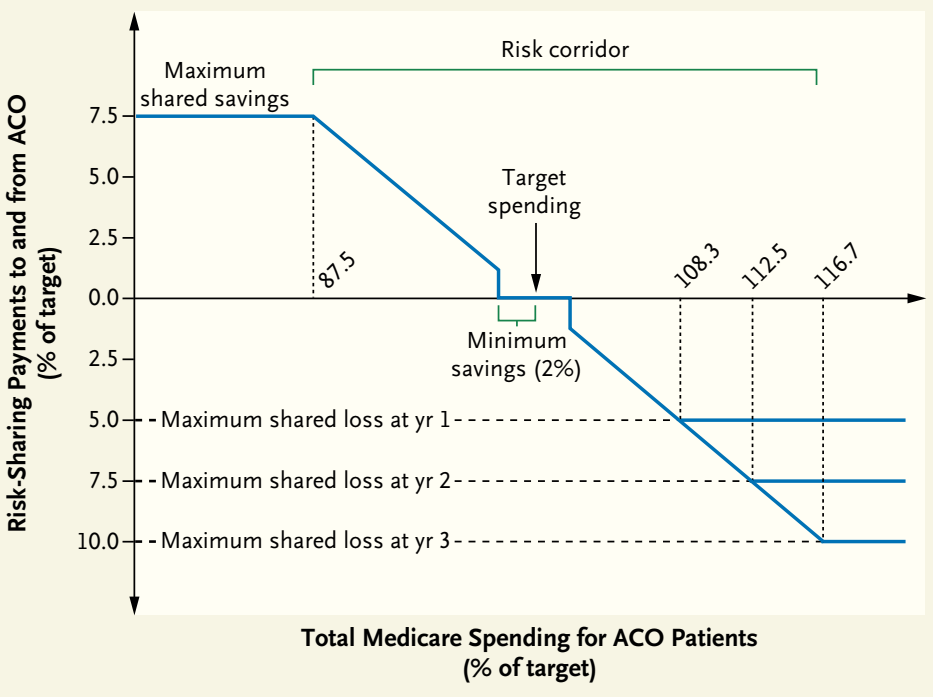

Consequences of Risk Sharing for ACOs That Accept Two-Sided Risk.

The solid blue line indicates the level of shared-savings payments to an ACO (where the line is above the $\mathrm{x}$ axis) or obligations to repay Medicare (where the line is below the $\mathrm{x}$ axis) as a function of Medicare spending for the population of patients attributed to the ACO. Shared savings are capped at $7.5 \%$ of the target, and the ACO receives $60 \%$ of any savings above the minimum savings threshold, which is $2 \%$ of the target spending level. When Medicare spending exceeds the target, the ACO is obligated to pay $60 \%$ of the excess with a similar $2 \%$ threshold for payment. Payments to Medicare for excess spending in the ACO are capped at $5 \%$ in the first year, and the cap increases by 2.5 percentage points in each of the subsequent 2 years.

care spending within a "risk corridor" (see diagram) that caps both gains and losses. For example, in the third year in which an ACO accepts two-sided risk, its obligations to repay CMS cease accruing once spending has reached $116.7 \%$ of the target (since ACO losses are capped at $10 \%$ of the target and losses borne by the ACO are $60 \%$ of the total, losses peak at overruns of $16.7 \% \times 60 \%=10 \%)$. Second, Medicare and the ACO share in every dollar of gain or loss, which means that an extra dollar of spending within the risk corridor reduces profits to the ACO by only 60 cents.

The proposed payment arrangement also differs from that used in Medicare's Physician Group Practice (PGP) demonstration, in which providers were eligible for shared savings but took on no downside risk. Introducing this risk has two advantages: it addresses the criticism that a shared-savings approach alone is too weak to force fundamental change in the care delivery $\operatorname{model}^{1}$; and it increases the range of costs over which an ACO's profits vary with costs, providing greater incentives to manage utilization.

A two-sided risk-sharing model is not without potential pitfalls, however. Some have expressed concern that downside risk could bring a return of the worst consequences of the managed-care era, including patient backlash and provider insolvency. ${ }^{2}$ Another prominent worry about more intensive risk sharing is that providers will seek to avoid high-cost patients. Although such possibilities cannot be eliminated, quality measure- ment with pay for performance, lack of patient lock-in, and caps on gains and losses should mitigate these unintended consequences.

Critics in both the provider and the policy communities have expressed concern that few organizations will sign up as ACOs, given the payment structure. This participation question goes beyond the desire to attain a critical mass of ACOs: Medicare seeks to improve the delivery of care by a broad range of providers, not just those that already manage care efficiently. It therefore needs providers that have room for improvement to take a chance on the new payment model.

Given the unfavorable reaction of many provider organizations, some additional steps to ensure participation are warranted. Indeed, CMS has already made clear that the two proposed paths are not the only bases on which providers can become ACOs. Alternative options will be available to at least some applicants through pilots initiated by the Center for Medicare and Medicaid Innovation. For example, providers that meet high standards for infrastructure and experience with population-based payment can apply to become Pioneer ACOs and take on greater risk with a lower threshold before shared savings kick in (1\%). But it may be worthwhile for CMS to do more to tip the balance for the ACO program that is open to all.

We see preserving the twosided risk model in the final regulations as a priority because it creates the kind of high-powered incentives to control costs that are urgently needed. Moreover, many ACO-like entities ac- 
cept two-sided risk contracts already. But CMS could do more to increase the upside for ACO participants to ensure broadbased participation.

First, the agency could offer a complement of early-adopter financial incentives (such as more generous shares of savings in the first 3 years of the program and loans to finance start-up costs) to front-load more of the benefits. Lowering or eliminating the requirement for achieving minimum savings before ACOs can reap a share of the gains (i.e., the 2-to-3.9\% savings required before shared savings begin) would also increase the benefits of participation. In a situation of two-sided risk, in particular, the rationale for such required minimum savings is not as clear.

Alternatively, there may be barriers to participation that CMS could lower without committing substantial additional resources. Under the draft regulations, providers would be obligated to meet a number of potentially costly documentation and data-collection requirements to become an ACO. For exam- ple, some provider groups have voiced concerns about the large numbers of quality measures (more than 60) that ACOs will be required to track and report on in the first 3 years. CMS could meet providers at least partway on another key issue that providers have highlighted: the lack of prospective assignment to an ACO of the beneficiaries whose costs will be counted in any shared-savings calculation. Prospective identification of enrollees that belong to an ACO would make it possible for providers to conduct outreach and more effectively manage population health. CMS might allow beneficiaries that prospectively enroll in an ACO to share in the savings that the ACO realizes, perhaps through a lower Part B premium.

The vision underlying the $\mathrm{ACO}$ movement - of provider accountability that goes beyond delivering an individual service and of care that is integrated and patientfocused - is one worth pursuing with bold steps. CMS has many good ideas in its ACO proposal. We believe that the final risk-sharing methods should build off this model - retaining the possibility of losses as well as savings - but front-load the benefits more and provide the tools and flexibility that provider groups will need to rationalize the delivery of medical care. Of course, the regulations are just the beginning of bringing ACOs to Medicare. CMS will have to develop capabilities to work in new ways with providers, sharing data and information in a timely manner, supporting change with technical assistance, and monitoring patient care for potential adverse consequences.

Disclosure forms provided by the authors are available with the full text of this article at NEJM.org.

From the Department of Health Policy and Management, Harvard School of Public Health, Boston (M.B.R.); the Department of Economics, Harvard University, Cambridge, MA (D.M.C.); and the Georgetown Public Policy Institute, Georgetown University, Washington, DC (J.F.).

This article (10.1056/NEJMp1106012) was published on July 13, 2011, at NEJM.org.

1. Berenson RA. Shared savings program for accountable care organizations: a bridge to nowhere? Am J Manag Care 2010;16:721-6.

2. Fisher DW. Medicare shared savings program: accountable care organizations. June 6 , 2011 (letter). (http://www.amga.org/Advocacy/ ACO/ACOCommentsFINALJune6.pdf.) Copyright (๑) 2011 Massachusetts Medical Society. 